\title{
ANTIPARASITIC EFFICACY OF FIPRONIL IN WISTAR RATS NATURALLY INFESTED BY Polyplax spinulosa (BURMEISTER, 1839)
}

\author{
EFICÁCIA ANTIPARASITÁRIA DO FIPRONIL EM RATOS WISTAR NATURAMENTE \\ INFESTADOS POR Polyplax spinulosa (BURMEISTER, 1839)
}

\author{
A. C. MORAES ${ }^{1}$, E. J. R. PRADO ${ }^{2}$, M. A. A. BELO ${ }^{3}$
}

\section{SUMMARY}

Based on the importance of pediculosis by Polyplax spinulosa for rodents, this study evaluated two treatments against this louse in naturally infested Wistar rats. 21 adult male rats were randomly distributed into three groups $(\mathrm{n}=7)$ : T1 = treated with the association of cypermethrin $(5 \%)$, dichlorvos $(45 \%)$ and piperidine butoxide $(25 \%)$ administered topically by spraying; $\mathrm{T} 2=$ treated with fipronil $1 \mathrm{mg}$. $\mathrm{Kg}^{-1}$ administered topically by spot on; $\mathrm{T} 3=$ untreated animals (control). In the initial phase, animals were housed in cages and wrapped in white cotton fabrics for evaluating $4,12,24$ and 48 hours post-treatment (HPT) to count the number of lice present in the external environment. In the second phase, the groups were transferred to polypropylene boxes for antiparasitic evaluation 7, 14 and 21 days post-treatment (DPT) by direct inspection of eggs and lice presence in the animals. The results showed higher lice counts 4 HPT, representing $41 \%$ of the total, and these findings were strongly influenced by the control animals with $20.51 \%$. However, rats treated with fipronil had the highest counts with 24 HPT, representing $14.36 \%$ of lice. No variation in lice counts was observed in T1 (pharmacological association). The efficacy study in the animals revealed absence of lice and presence of eggs in treated animals (T1 and T2) at 7 and 14 DPT. In the $21^{\text {st }}$ day, rats treated with the pharmacological association presented lice whereas fipronil treated rats remained only with eggs not hatched. However, this study demonstrated that Fipronil at $1 \mathrm{mg} \cdot \mathrm{kg}^{-1}$ via spot on is an effective option for the control of $P$. spinulosa in Wistar rats, while treatment with the association of cypermethrin (5\%), dichlorvos (45\%) and piperidine butoxide (25\%) was not effective against eggs viability and hatching, resulting in the return of parasitic infestation.

KEY-WORDS: Phenylpyrazole. Organophosphorus. Pyrethroid. Pediculosis.

\section{RESUMO}

Baseado na importância da pediculose por Polyplax spinulosa em roedores, este estudo avaliou dois tratamentos para controle deste piolho em ratos Wistar naturalmente infestados. Para tal, 21 ratos adultos machos foram distribuídos em três grupos $(\mathrm{n}=7)$ : $\mathrm{T} 1=$ tratados com associação farmacológica cipermetrina $(5 \%)$, diclorvos $(45 \%)$ e butóxido de piperolina $(25 \%)$, via tópica por pulverização; T2= tratados com fipronil $1 \mathrm{mg}$. $\mathrm{Kg}^{-1}$ via tópica por "Spot on"; T3= animais não tratados (controle). Na fase inicial do estudo, os animais foram acondicionados em gaiolas e envolvidos em tecidos de algodão branco para avaliação 4, 12, 24 e 48 horas pós-tratamento (HPT) do número de piolhos presentes no tecido (ambiente externo). Na segunda etapa, os grupos foram transferidos para caixas de polipropileno para avaliação antiparasitária 7, 14 e 21 dias pós-tratamento (DPT) por inspeção direta da presença de ovos e piolhos nos animais. Os resultados revelaram maiores contagens de piolho 4 HPT, representando $41 \%$ do total, sendo estes achados fortemente influenciados pelos animais controles com 20,51\%. Entretanto, ratos tratados com fipronil apresentaram as maiores contagens com 24 HPT representando 14, 36\% dos piolhos. Não se observou variações nas contagens de piolho em animais do grupo T1 (associação de fármacos). O estudo de eficácia nos animais revelou ausência de piolhos e presença de ovos nos animais tratados (T1 e T2) no 7 e $14^{\circ}$ DPT. Na avaliação realizada $21^{\circ}$ DPT, ratos tratados com a associação farmacológica apresentaram piolhos enquanto ratos tratados com fipronil permaneceram somente com ovos não eclodidos. Contudo, este estudo demonstrou que o fipronil via "Spot on" em dose única na concentração de $1 \mathrm{mg} . \mathrm{kg}$ " ${ }^{1}$ é uma opção eficaz para o controle de $P$. spinulosa em ratos Wistar, enquanto o tratamento com a associação de cipermetrina (5\%), diclorvos $(45 \%)$ e butóxido de piperolina $(25 \%)$ não se mostrou eficaz contra a viabilidade e eclosão dos ovos, resultando na reinfestação dos animais.

PALAVRAS-CHAVE: Fenilpirazole. Organosfosforados. Piretróide. Pediculose.

\footnotetext{
${ }^{1}$ Fundação Universidade Federal de Rondônia, Campus Rolim de Moura, Rondônia, Brasil; Universidade Brasil, Campus de Descalvado, São Paulo. Email.: alecris@unir.br

${ }^{2}$ Universidade Federal do Mato Grosso, Campus Sinop, Mato Grosso, Brasil; Universidade Brasil, Campus de Descalvado, São Paulo. Email.: ed_johnny@ hotmail.com

${ }^{3}$ Universidade Brasil, Campus de Descalvado, São Paulo. Email.: maabelo@ hotmail.com
} 


\section{INTRODUCTION}

A survey conducted in the United States evaluated the prevalence of sanitary outbreaks in rodent facilities, revealing that infections of viral etiology decreased over the years, however, the casuistic of bacterial and ectoparasitic diseases remained constant, even with the use of sanitary barriers (MARX et al., 2017). According to these authors, the research credibility results depends on the control of external interferences which are not peculiarities of the experimental objective, considering that animals with infectious and/or parasitic diseases impair research findings, in addition to compromise the animal welfare.

Novergicus Wistar rat is one of the most breeding lines in rodent facilities, since they present desirable characteristics such as short breeding cycle, genetic similarity with humans, ease of maintenance and management (MATTARAIA et al., 2012). On the other hand, Polyplax spinulosa frequently parasite rats in rodent facilities, being an ectoparasite belonging to order Phthiraptera and suborder Anoplura (sucking lice), and the transmission between animals is by direct contact, causing irritation, restlessness and constant scratching, especially behind the ears. Massive infestation can result in dermatitis and anemia (TAYLOR et al., 2017). In addition, $P$. spinulosa can act as a vector of Mycoplasma haemomuris, Rickettsia typhi, Trypanosoma lewisi, Borrellia duttoni and Brucella brucei (BAKER, 2006).

The use of antiparasitic drugs in sanitary management represents an important strategy in the control of ecto and endoparasites in veterinary medicine (CHARLIE-SILVA et al., 2018). Fipronil has been successfully used for the control of ectoparasites in cattle (SOUZA et al., 2014), dogs (DAVOUST et al., 2003; BONNEAU et al., 2010) and cats (PAYNE et al., 2001; SCARAMPELLA et al., 2005; KUŽNER et al., 2013), as well as the use of formulations composed by pyrethroids and organophosphates (SOARES et al., 2009, BELO et al., 2012, SOUZA et al., 2017).
Based on the importance of health management and the need to establish new therapeutic protocols for pediculosis in laboratory animals, this study aimed to evaluate the antiparasitic efficacy of fipronil $1 \%$ and the formulation composed by cypermethrin $5 \%+$ Diclorvos $45 \%+25 \%$ piperonyl butoxide, both administered through topical route in Wistar rats naturally parasitized by $P$. spinulosa.

\section{MATERIAL AND METHODS}

For the study were used 21 male rats with 12 months of age $(250 \mathrm{~g} \pm 50 \mathrm{~g})$, fed with Labina ${ }^{\circledR}$ commercial food and water ad libitum. Rats were reared under controlled temperature $\left(24\right.$ to $\left.28^{\circ} \mathrm{C}\right)$, relative humidity (50 to $70 \%)$ and photo period (12 light hours) and was conducted in the Brazilian autumn (May and June). The experiment was conducted at Brasil University, approved by the Institutional Ethics Committee for Research (process number 3042-3262 / 10), according to experimental protocols for good clinical practice (BRASIL, 2009).

Rats were naturally infested by $P$. spinulosa (Burmeister, 1839) (Figure 1) showing pruritus and bristling. The animals were randomly distributed into three groups of 7 animals each, constituting the treatments: $\mathrm{T} 1=$ cypermethrin + dichlorvos + piperoline butoxide; T2 = treatment with fipronil and T3 = untreated animals (control). The first therapeutic protocol consisted of administering the pharmacological combination: cypermethrin (5\%), dichlorvos (45\%) and piperidine butoxide (25\%) prepared in the proportion of $1 \mathrm{~mL}$ of the compound to $400 \mathrm{~mL}$ of water. The spray method was used to distribute the product over the entire body of the animal resulting in the concentration of $2.5 \mathrm{mg}$ of cypermethrin, $22.5 \mathrm{mg}$ of dichlorvos and $12.5 \mathrm{mg}$ of piperidine butoxide per kilogram of body weight. The second treatment consisted of fipronil $1 \%$, administered through topical route spot on, in the neck region at the concentration of $1 \mathrm{mg} \cdot \mathrm{kg}^{-1}$.

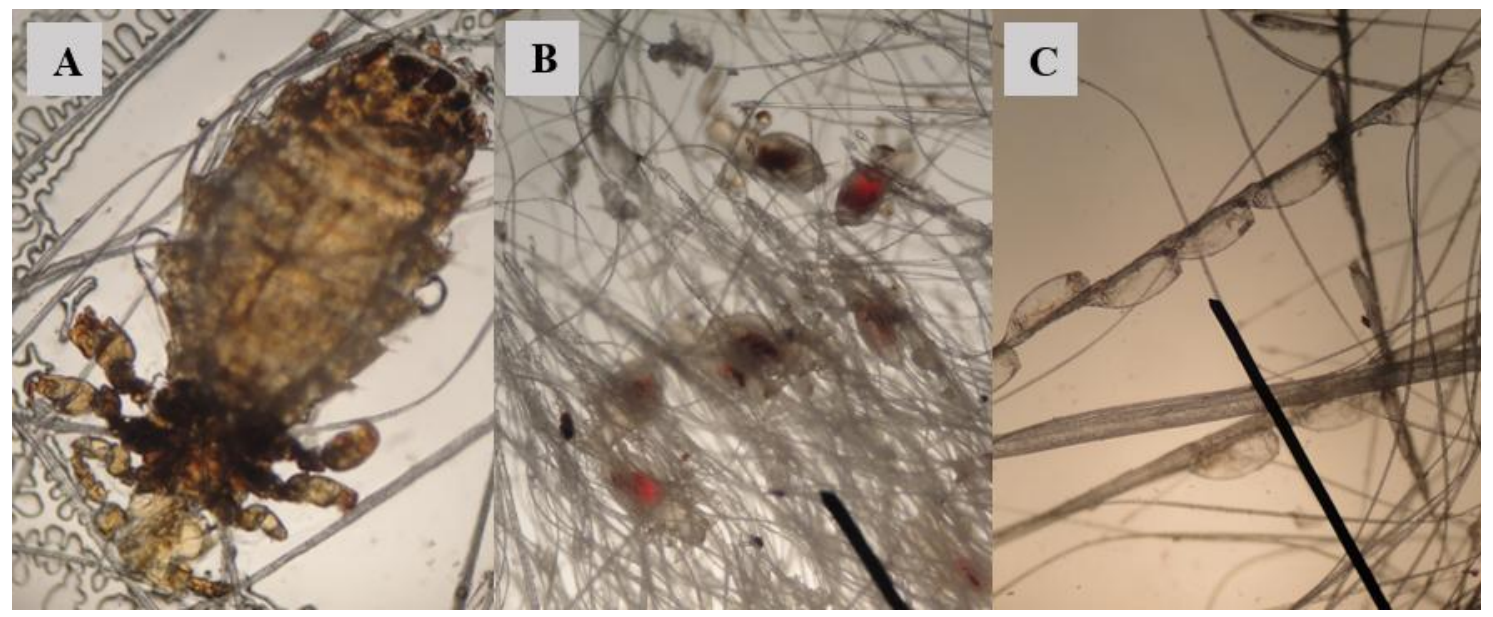

Figure 1 - P. spinulosa: (A) Lice (100x magnification); (B) Lice (40x); (C) Eggs (100x). 
After treatment, each rat group (seven animal) was reared in an individual cage $(60 \times 40 \times 30 \mathrm{~cm})$, wrapped in white cotton fabrics. At 4, 12, 24 and 48 hours post-treatment (HPT) the cotton fabric was removed from the cage, and immediately substituted with another. The removed tissues were evaluated by direct inspection and the respective parasite counts were determined. In order to evaluate the parasite presence in the animal body, the experimental groups were transferred to sterilized boxes and kept in different rooms with the same characteristics, to avoid cross infestation. After 7, 14 and 21 days posttreatment (DPT), each animal was observed by direct inspection to verify the presence of lice and eggs. The experimental protocol and all the antiparasitic analysis performed in this investigation are in compliance with Portaria $\mathrm{N}^{\circ} 48$ from MAPA, Brazilian Ministry of Agriculture Livestock and Food Supply (MAPA, 1997), which guides studies for registrations of veterinary products in Brazil.

Lice counts were evaluated by a contingency table followed by a Chi-square Test, using the null hypothesis that the experimental groups did not differ, accepting a $5 \%$ of probability. Simple correspondence analysis was also performed to establish the inertia between the experimental data, in order to search for associative patterns between treatment and time analyzed for parasitism. For evaluation over the days, descriptive statistics regarding the absence and presence of lice and eggs were also followed by multiple correspondence analyses.

The BoxCox test $(\lambda=1)$ and the Shapiro-Wilk test (P> 0.05) were used to establish the homoscedasticity and normality hypothesis of internally standardized residues. All statistical analyzes were processed in the SAS® software (Statistical Analysis System), version 9.3 (SAS, 2012).

\section{RESULTS AND DISCUSSION}

Contingency analysis (Table 1) correlates the number of lice found in the external environment with the expectation for that period (Chi-Square test $=p$ $<0.05)$. The results revealed higher lice counts 4 HPT, representing $41 \%$ of the total. The control animals counts were the most significant, representing $20.51 \%$ and with a high number of lice $(n=40)$, when compared to the number of lice expected for this period $(\mathrm{n}=32)$. However, 28 ectoparasites were counted for the rats treated with fipronil $24 \mathrm{HPT}$, ie, a higher expectation score $(n=19)$, even higher than the counts observed in the control group $(n=15)$ and treated with the pharmacological association $(n=12)$.

Table 1 - Frequency and expectation of lice count from the external environment of wistar rats submitted to several treatments.

\begin{tabular}{|c|c|c|c|c|c|}
\hline \multirow{2}{*}{$\begin{array}{l}\text { Treatment } \\
\text { Frequency }\end{array}$} & \multicolumn{5}{|c|}{ Hours } \\
\hline & & & & & \\
\hline Expected & 4 & 12 & 24 & 48 & Total \\
\hline \multicolumn{6}{|l|}{ Percent } \\
\hline \multirow{3}{*}{ Control } & 40 & 16 & 15 & 9 & 80 \\
\hline & 32.82 & 14.36 & 22.56 & 10.26 & \\
\hline & $20.51 \%$ & $8.21 \%$ & $7.69 \%$ & $4.62 \%$ & $41.03 \%$ \\
\hline \multirow{3}{*}{ Pharmacological association* } & 22 & 7 & 12 & 6 & 47 \\
\hline & 19.28 & 8.43 & 13,25 & 6.02 & \\
\hline & $11.28 \%$ & $3.59 \%$ & $6.15 \%$ & $3.08 \%$ & $24.10 \%$ \\
\hline \multirow{3}{*}{ Fipronil } & 18 & 12 & 28 & 10 & 68 \\
\hline & 27.89 & 12.20 & 19.18 & 8.71 & \\
\hline & $9.23 \%$ & $6.15 \%$ & $14.36 \%$ & $5.13 \%$ & $34.87 \%$ \\
\hline \multirow{2}{*}{ Total } & 80 & 35 & 55 & 25 & 195 \\
\hline & $41.03 \%$ & $17.95 \%$ & $28.21 \%$ & $12.82 \%$ & $100.00 \%$ \\
\hline \multicolumn{6}{|l|}{ Probability Chi-Square: 0,0438 } \\
\hline *Cypermethrin, dichlorvos and & nyl butc & & & & \\
\hline
\end{tabular}

The correspondence analysis findings (Figure 2) corroborate the counts observed in the contingency study. It was also observed the correspondence of the control group $4 \mathrm{HPT}$, as well as of the group treated with fipronil 24 HPT.

The highest number of ectoparasites found in the control group 4 HPT was due to the fact that they had not received any treatment and the lice maintained with continuous blood spoliation. The continuous lesion stimulus suggests the hypothesis that the parasitism favored the release of histamine, an important inflammatory mediator, which causes pruritus (HEYER et al., 1997), and associated to scratching there was a greater removal of lice to external environment.

Increase of lice 24 HPT observed in the treatment with fipronil is due to the drug characteristics which do not act by direct contact with the parasite body but by continuous intoxication during the parasitism. In addition, fipronil has been shown to play 
a role in the transport of chloride ions in the cell membrane through the $\gamma$-aminobutyric acid receptor (GABA) (ZHAO et al., 2003) and also acts on glutamate receptors coupled to chloride channels (NARAHASHI et al. 2010). The GABA neurotransmitter presence in the synaptic junctions results in uncontrolled central nervous system (CNS) activity and consequent hyperexcitability of the parasite (ZHAO et al., 2003). This effect on CNS may have contributed to the pronounced counts of lice in the external environment 24 HPT.

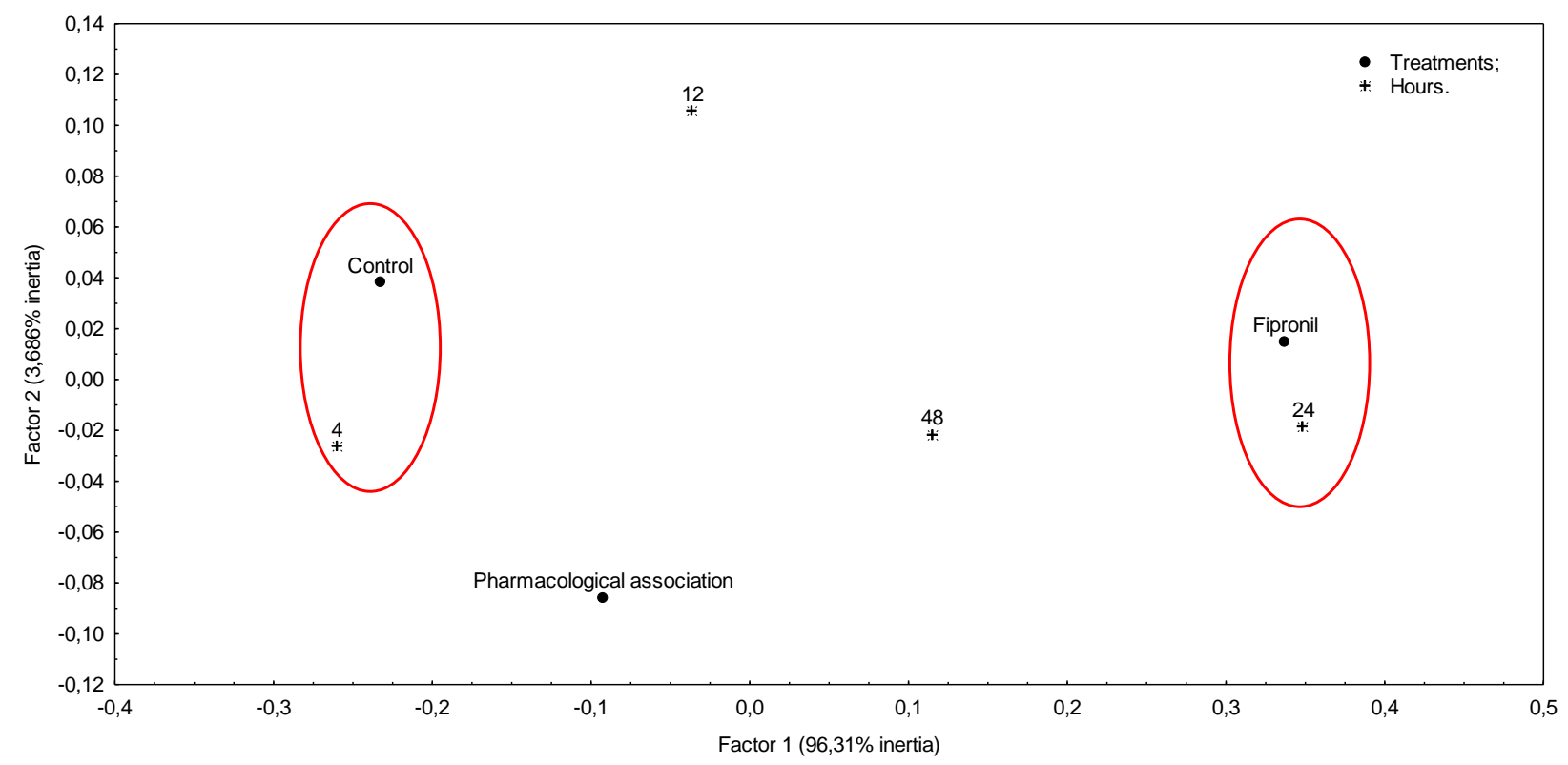

Figure 2 - Behavior patterns between the treatments and the periods analyzed for control of P.spinulosa in wistar rats by correspondence analysis.

Differently to the results observed with the use of cypermethrin, dichlorvos and piperonyl butoxide treatment, which aims to act directly on the louse body, no significant variations were observed in the lice counts between the different periods. The organophosphorus dichloride bind the cholinesterase enzyme receptor, causing accumulation of acelticoline, resulting in motor incoordination and parasite death, while the pyrethroid type II cypermethrin inhibits the sodium channels, preventing the action potential and thus leading to a blockage of neural activity, also it can act on GABA type receptors only in high concentration (COSTA, 2008). Piperonyl butoxide presents synergistic effect on the cytochrome P450 system, decreasing drug metabolism by the liver. The joint action of these active principles did not result in significant changes in lice counts in the external environment.

All groups presented lower lice counts 48 HPT than the other observation periods (Table 1), probably due to lice removal in the counting procedure, with this management there was no possibility of lice returning to the host and the period was short for egg hatching. In the cycle of lice, approximately 6 days are observed for egg hatching (TAYLOR et al., 2017) and the initial evaluation phase of this study contemplated only 2 days. On the other hand, the pruritus continued with lower intensity even after a decrease in the number of lice. This was due to the inflammatory response to repair skin lesions, possibly by continuous chemical mediators release of inflammatory mediators (EMING et al., 2007), so dead or intoxicated lice continued to be taken in less quantity to the external environment in the act of scratching.

The parasitism comparative study (Table 2) revealed the absence of lice and presence of eggs in all animals submitted to pharmacological treatment 7 and 14 DPT (Groups T1 and T2). In the $21^{\text {st }}$ DPT evaluation, rats treated with the pharmacological association presented lice whereas to fipronil treated rodents remained only with eggs not hatched (Table 2).

Correspondence analysis evaluates the presence and absence of lice and/or eggs 7, 14 and 21 DPT (Figure 3), we observed a grouping between the observations of treatment with fipronil to the absence of lice and the possible presence of lice eggs, corroborating the findings described in Table 2.

The efficacy result was demonstrated by the individual evaluation over the days. Treatment with fipronil proved to be effective in the control of pediculosis by action on lice and egg of $P$. spinulosa. In the pharmacokinetic of fipronil, the drug accumulates in the cutaneous adipose tissue, favoring its excretion along with sebaceous secretion (COCHET et al., 1997), therefore, coming directly into contact with lice eggs and presenting a long residual period (FAO, 1998). Study conducted in rats with radiolabeled fipronil, administered by oral route at a dose of $4 \mathrm{mg} / \mathrm{kg}$, plasma peak was 5.5 hours after administration, elimination half-life of 183 hours in males and 245 hours in females, showing distribution 
throughout the body, but with a higher concentration in adipose tissue (FAO, 1998).

Pharmacological association treatment (T1) did not present an effect on eggs due to the appearance of new lice; this fact may be due to pharmacodynamic and pharmacokinetic characteristics, resulting in the low efficacy in the control of $P$. spinulosa, unlike the elimination characteristic of fipronil by sebaceous gland secretion (COCHET et al, 1997) that favored a long antiparasitic efficacy.

According to Marx et al. (2017), one of the most widely used active principles for treating lice in

Table 2 - Presence or absence of adult lice or eggs by individual direct examination in wistar rats submitted to several treatments.

\begin{tabular}{|c|c|c|c|}
\hline Treatment & & Days & \\
\hline $\begin{array}{l}\text { Lice } \\
\text { Eggs }\end{array}$ & 7 & 14 & 21 \\
\hline \multirow{2}{*}{ Control } & present & present & present \\
\hline & present & present & present \\
\hline \multirow{2}{*}{$\begin{array}{l}\text { Pharmacological } \\
\text { association }\end{array}$} & absence & absence & present \\
\hline & present & present & present \\
\hline \multirow[t]{2}{*}{ Fipronil } & absence & absence & absence \\
\hline & present & present & present \\
\hline
\end{tabular}

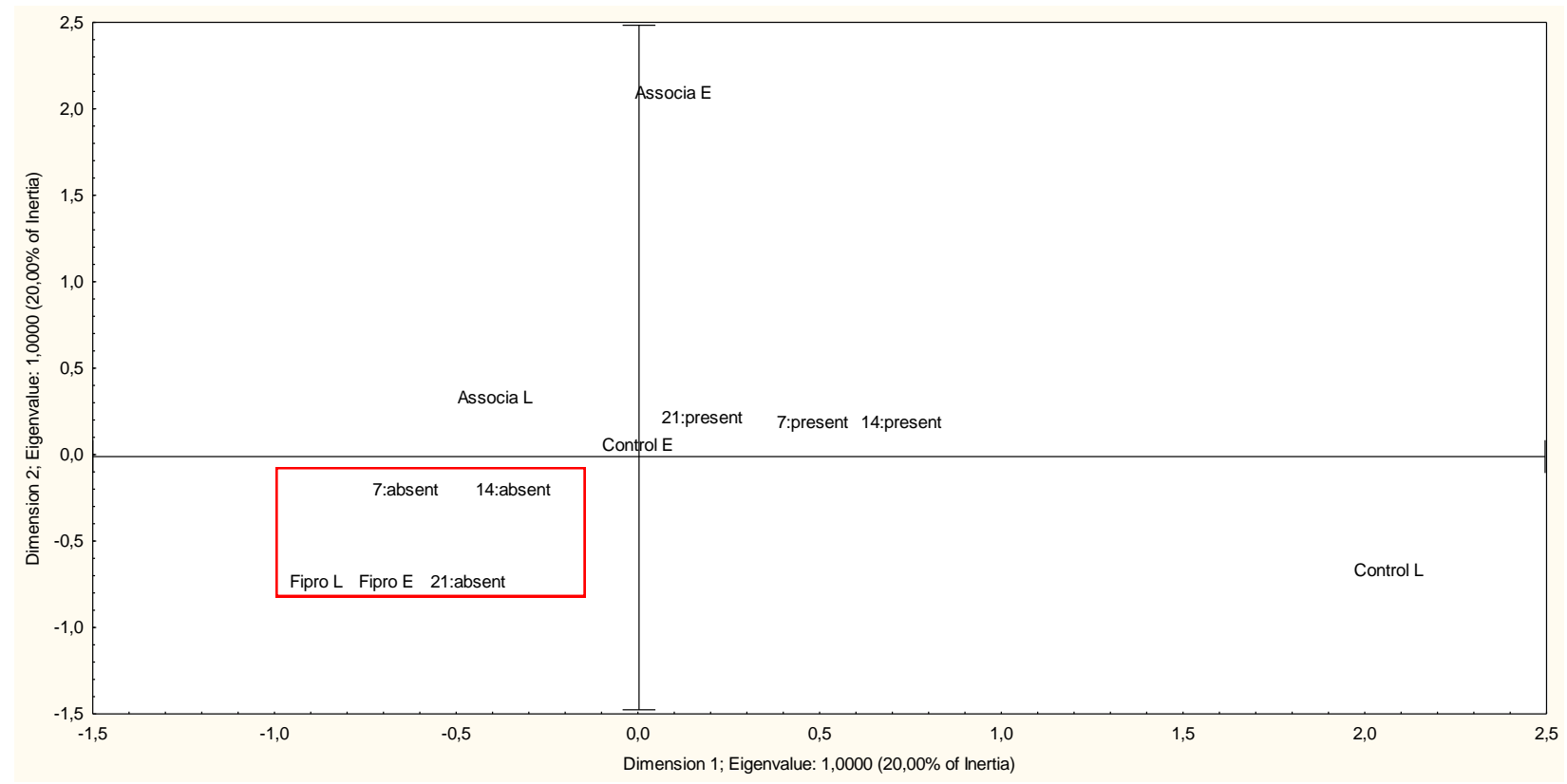

Figure 3 - Patterns between treatments: pharmacological association (Associa), Fipronil (Fipro) and control (Control) for presence or absence of lice (L) and eggs (E) over the days analyzed: 7, 14 and 21 days in wistar rats naturally parasitized by P.spinulosa in correspondence analysis.

\section{CONCLUSION}

This study demonstrated that fipronil at 1 mg. $\mathrm{kg}^{-1}$ via spot on is an effective option for the control of $P$. spinulosa in Wistar rats, while treatment with the association of cypermethrin (5\%), dichlorvos (45\%) and piperidine butoxide (25\%) was not effective against eggs viability and hatching, resulting in the return of parasitic infestation. the United States is ivermectin, with a two-dose protocol ranging from 7 to 10 days. However, fipronil has been shown to be an excellent option as a single dose protocol for controlling $P$. spinulosa in Wistar rats. It is noteworthy that in agreement with the results of this study, after the 21 days of experimental design, all animals not treated with fipronil were submitted to the present treatment protocol, aiming to promote animal welfare in our laboratory. 
(Ixodes ricinus) in dogs. Parasitology Research, v. 107, n. 3, p. 735-739, 2010.

BRASIL GUIA I:Boas Práticas Clínicas (BPC), Ministério da Agricultura Coordenação de Fiscalização de Produtos Veterinários, 2009. 30P.

BRASIL. Portaria $N^{\circ}$ 48/97. Regulamento técnico para licenciamento e/ou renovação de licença de produtos antiparasitários de uso veterinário. Brasília: MAPA, 1997.

BELO, M. A. A.; PRADO, E. J. R.; SOARES, V. E.; SOUZA, L. M.; MOTA, F. C. D., GIAM L. T. F., E GÍRIO, T. M. S. Eficácia de diferentes formulações no controle da mosca Haematobia irritans em bovinos naturalmente infestados. Bioscience Journal, v. 28, n. 2,2012 .

CHARLIE-SILVA, I.; SOUZA, L.M., BELO, M.A.A., MORAES, A. C., PRADO, E. J.R., MOLENTO, M.; MARCHIORI-FILHO, M. In vitro toxicity of cypermethrin and deltamethrin on the cattle tick Rhipicephalus microplus. Ars Veterinaria, v. 33, n. 2, p. 51-56, 2018.

COCHET, P.; BIRCKEL, P.; BROMET-PETIT, M.; BROMET, N.; WEIL, A. Skin distribution of fipronil by microautoradiography following topical administration to the beagle dog. European Journal of Drug Metabolism and Pharmacokinetics, v. 22, n. 3, p. 211-216, 1997.

COSTA, L. G. Toxic effects of pesticides. Casarett and Doull's toxicology: the basic science of poisons, p. 883-930, 2008 .

DAVOUST, B.; MARIE, J. L.; MERCIER, S.; BONI, M.; VANDEWEGHE, A.; PARZY, D.; BEUGNET, F. Assay of fipronil efficacy to prevent canine monocytic ehrlichiosis in endemic areas. Veterinary Parasitology, v. 112, n. 1-2, p. 91-100, 2003.

EMING S. A.; KRIEG T.; DAVIDSON, J.M. Inflammation in wound repair: molecular and cellular mechanisms. Journal of Investigative Dermatology, v. 127, n. 3, p. 514-525, 2007.

FAO, O. Pesticide Residues in food-1997. Report of the Joint Meeting of the FAO Panel of Experts on Pesticide Residues in Food and the Environment and the WHO Core Assessment Group on Pesticide Residues. Lyons, France. 22 Sept-1Oct 1997. FAO Plant Production and Protection Paper, v. 145, $1998 . \quad$ Disponível em: http://www.fao.org/docrep/w8141e/w8141e00.htm\#Co ntents

HEYER, G.; DOTZER, M.; DIEPGEN, T. L.; HANDWERKER, H. O. Opiate and $\mathrm{H} 1$ antagonist effects on histamine induced pruritus and alloknesis. Pain, v. 73, n. 2, p. 239-243, 1997.
KUŽNER, J.; TURK, S.; FOURIE, J. J.; GRACE, S.; MARCHIONDO, A. A.; RUGG, D. Efficacy of a novel fipronil spot-on for the treatment and control of induced infestations of adult cat fleas (Ctenocephalides felis) and castor bean ticks (Ixodes ricinus) on cats. Parasitology Research, v. 112, n. 1, p. 365-372, 2013.

MARX, J. O.; GAERTNER, D. J.; SMITH, A. L. Results of Survey Regarding Prevalence of Adventitial Infections in Mice and Rats at Biomedical Research Facilities. Journal of the American Association for Laboratory Animal Science, v. 56, n. 5, p. 527-533, 2017.

MATTARAIA, V. G. D. M.; MOURA, A. S. A. M. T. Produtividade de ratos Wistar em diferentes sistemas de acasalamento. Ciência Rural, p. 1490-1496, 2012.

NARAHASHI, T.; ZHAO, X.; IKEDA, T.; SALGADO, V. L.; YEH, J. Z. Glutamate-activated chloride channels: unique fipronil targets present in insects but not in mammals. Pesticide biochemistry and physiology, v. 97, n. 2, p. 149-152, 2010.

PAYNE, P. A.; DRYDEN, M. W.; SMITH, V.; RIDLEY, R. K. Effect of $0.29 \%$ w/w fipronil spray on adult flea mortality and egg production of three different cat flea, Ctenocephalides felis (Bouché), strains infesting cats. Veterinary parasitology, v. 102, n. 4, p. 331-340, 2001.

PEREIRA, J. S.; DE SOUZA FONSECA, Z. A. A.; GADELHA, I. C. N.; DE PAIVA, K. A. R.; AHID, S. M. M. Parasitismo por Polyplax spinulosa Burmeister, 1839 (Anoplura) em ratos Wistar, Rattus norvegicus Berkenhout, 1769. Revista Brasileira de Higiene e Sanidade Animal, v. 9, n. 1, p. 105-110, 2015.

SCARAMPELLA, F., POLLMEIER, M., VISSER, M., BOECKH, A., \& JEANNIN, P. Efficacy of fipronil in the treatment of feline cheyletiellosis. Veterinary parasitology, v. 129, n. 3-4, p. 333-339, 2005.

SAS (Statistical Analisys System Institute). The SASSystem for Windows: user's guide. Versão 9.3. Cary, 2012.

SOARES, V. E.; BELO, M. A. A.; DE SOUZA, L. M.; GUIARO, C. R.; BORTOLETTO JR, O.; GÍRIO, T. M. Associação de cipermetrina, diclórvos e butóxido de piperolina contra Rhipicephalus (Boophilus) microplus em bovinos naturalmente infestados. Archives of Veterinary Science, v. 14, n. 1, 2009.

SOUZA, A. P.; PAIM, F.; BELLATO, V.; SARTOR, A. A.; MOURA, A. B.; ROSA, L. D.; MIQUELLUTI, D. J. Avaliação da eficácia do fipronil em Rhipicephalus (Boophilus) microplus em tratamentos consecutivos. Arquivo Brasileiro de Medicina Veterinária e Zootecnia, v. 66, n. 1, p. 55-60, 2014. 
SOUZA, L. M.; BELO, M. A. A.; SILVA, I. C. Eficácia de diferentes formulações de acaricidas sobre larvas de Rhipicephalus sanguineus (Latreille, 1806)(Acari: Ixodidae) e Rhipicephalus (Boophilus) microplus (Canestrini, 1887)(Acari: Ixodidae). Biotemas, v. 30, n. 1, p. 65-72, 2017.

TAYLOR, M. A.; COOP, R. L.; WALL, R. L. Parasitologia Veterinária. Grupo Gen-Guanabara Koogan, 2017.
TOTIS, M.; FISHER, P.J. Fipronil: Tissue kinetic study in the rat. Unpublished report No. SA94255 from Rhone-Poulenc Agrochimie Toxicology. Submitted to WHO by Rhone-Poulenc, Inc., Research Triangle Park, NC, USA, 1994

ZHAO, X.; SALGADO, V. L.; YEH, J. Z.; NARAHASHI, T. Differential actions of fipronil and dieldrin insecticides on GABA-gated chloride channels in cockroach neurons. Journal of Pharmacology and Experimental Therapeutics, v. 306, n. 3, p. 914-924, 2003. 